\title{
Effect of age on the association between p16CDKN2A methylation and DNMT3B polymorphism in head and neck carcinoma and patient survival
}

\author{
LUCYANA CONCEIÇÃO FARIAS ${ }^{1}$, CARLOS ALBERTO DE CARVALHO FRAGA ${ }^{1}$, \\ MARCOS VINÍCIUS MACEDO DE OLIVEIRA ${ }^{1}$, THIAGO FONSECA SILVA ${ }^{1}$, \\ LUCIANO MARQUES-SILVA ${ }^{2}$, PAULA ROCHA MOREIRA ${ }^{2}$, ALFREDO MAURÍCIO BATISTA DE-PAULA ${ }^{1}$, \\ RICARDO SANTIAGO GOMEZ ${ }^{2}$ and ANDRÉ LUIZ SENA GUIMARÃES ${ }^{1}$
}

\author{
${ }^{1}$ Department of Dentistry, Universidade Estadual de Montes Claros, Montes Claros; ${ }^{2}$ Department of Clinical, \\ Surgery and Oral Pathology, School of Dentistry, Universidade Federal de Minas Gerais, Belo Horizonte, Brazil
}

Received December 30, 2009; Accepted February 8, 2010

DOI: 10.3892/ijo_00000664

\begin{abstract}
De novo DNA methylation is a relevant epigenetic mechanism, which represses gene transcription and commonly inactivates tumor suppressor genes in carcinogenesis. A single nucleotide polymorphism of DNMT3B, C46359T $(-149 \mathrm{C} \rightarrow \mathrm{T})$ was reported to modulate individual's susceptibility to cancer. We investigated the role of this polymorphic variant regarding the methylation status of the p16CDKN2A gene in young and older patients with head and neck squamous cell carcinoma (HNCC) matched by the TNM staging system, together with its impact on patients survival. The results showed that the presence of the allele $\mathrm{T}$ of the polymorphism DNMT3B $(-149 \mathrm{C} \rightarrow \mathrm{T})$ was associated with advanced TNM staging and smoking habit, but no association was found between this polymorphisms and DNMT3B immunostaining. While p16CDKN2A methylation was significantly associated with smoking habit in older patients, this parameter was associated with family history of cancer in young patients. Moreover, in older patients the absence of p16CDKN2A promoter methylation had a negative impact on survival. In conclusion, nucleotide polymorphism of DNMT3B is not associated with methylation of $p 16 C D K N 2 A$ gene in HNSCC. The association of $p 16 C D K N 2 A$ gene methylation with smoking, family history of cancer and survival is dependent on age.
\end{abstract}

Correspondence to: Dr André Luiz Sena Guimarães, Universidade Estadual de Montes Claros, Hospital Universitário Clemente de Faria, Laboratório de Pesquisa em Saúde, Avenida Cula Mangabeira, 562, Montes Claros, Minas Gerais cep 39401-001, Brazil

E-mail: andreluizguimaraes@gmail.com

Key words: DNMT3B, polymorphism, p16CDKN2, methylation, head and neck cancer

\section{Introduction}

Head and neck squamous cell carcinoma (HNSCC) is the sixth most common type of cancer and represents 350,000 cancer deaths worldwide every year $(1,2)$. It includes malign epithelial neoplasms that arise in the paranasal sinuses, nasal cavity, oral cavity, pharynx, and larynx (3). In Brazil, considering only oral cavity, the estimate for 2009 is 10,300 new cases of squamous cell carcinoma according to the National Institute of Cancer (INCA) (4). HNSCC has been regarded as a disease that generally affects men between the sixth through the eighth decades of life following long-term exposure to smoking and alcohol intake (5). However, an increase in the incidence of head and neck cancer among younger patients under the age of 45 years has been reported worldwide (6-12). Evidence suggests that carcinogenesis in young adults have a distinct mechanism of disease and often is not associated with classic risk factors for HNSCC $(6-10,12)$. Differences in prognosis were observed in HNSCC patients according to age (13). Classically, the development of cancer in human has been viewed as a disease related to progressive genetic alterations (14-16). Recently, evidence indicates that not only genetic factors but also epigenetic modifications are similarly relevant in carcinogenesis $(17,18)$. In contrast to genetic alterations, epigenetic modifications are reversible $(19,20)$. This feature makes them attractive targets for therapeutic intervention $(21,22)$.

The DNA methylation is the addition of methyl radicals to specific regions of DNA containing, predominantly, cytosine nucleotides. It is catalyzed by a family of enzymes denominated DNA methyltransferase (DNMTs), including three catalytically active enzymes - DNMT1, DNMT3a and DNMT3b. Although these enzymes act cooperatively to establish a pattern of genomic methylation, specific functions are performed by DNMTs. DNMT1 is an enzyme of maintenance, while DNMT3a and DNMT3b are responsible for the establishment of a new methylation pattern, known as de novo methylation $(23,24)$. In addition to an important role in controlling gene activity, embryonic development, genomic 
imprinting (25), methylation has been associated with the development of cancer by transcriptional inactivation of tumor suppressor genes $(17,25)$. The pattern of methylation has been linked to several cancer types, such as lung (17), oral (26) and head and neck cancer (27). Hypermethylation as well as hypomethylation can promote the development of the carcinogenesis (28). Genetic polymorphisms of the DNMT3b gene were described and it is associated with susceptibility of a variety of cancers (29-34), including head and neck squamous cell carcinoma (35-37). Genetic polymorphism of DNMT3b was described in the -149 position (C46359T). It was postulated that the variant $\mathrm{T}$ might regulate this gene, promoting an increase in its expression, and resulting in a predisposition to aberrant de novo methylation of tumor suppressor genes and repair genes (38-40).

The $p 16 C D K N 2 A$ is a tumor suppressor gene that encodes a cyclin-dependent kinase inhibitor which plays an important role in the regulation of the G1/S phase cell cycle checkpoint. The inactivation of this gene was observed in many tumor types (41-45). P16 protein can be inactivated by point mutation, homozygous deletion and methylation of the promoter region $(46,47)$. Although increased expression of DNMT3B gene is associated with $\mathrm{P} 16$ inactivation in esophageal and lung cancer $(48,49)$, their role in HNSCC has not been established. We hypothesized that the polymorphism of DNMT3B (C46359T) could promote high levels of DNMT3B expression and induce consequently p16CDKN2A methylation. Furthermore, we attempted to verify whether this possible association is dependent on age and has impact on patient survival.

\section{Patients and methods}

Patients. The present analysis was based on a case-control study design. The patients were recruited from databases of the head and neck surgery services in Montes Claros, Brazil from 1996 through 2007 (6). The study group included 75 patients with HNSCC consisting of a case group of 25 patients aged $\leq 45$ years (young) and a control group of 50 patients aged $>45$ years (older patients), that were matched for TMN staging, smoking and alcohol intake. Young and older patients were from the same geographical area.

Clinical data. The mean age was 42.1 years (SD 3.17 years; range, 33-45 years) for young and 62.2 years (SD 8.0 years; range, 49-82 years) for older patients with HNSSC. Physical description of skin color was not used because, in Brazil, it is a poor predictor of genomic ancestry $(50,51)$. The study was approved by the local Ethics Committee (process no. 1085). Information on age, sex, tobacco smoking, alcohol drinking, medical history, family cancer history, tumor site, TNM clinical staging, and survival were obtained from medical charts.

All patients were staged according to the UICC TNM Classification of Malignant Tumors (1997) (52). Lesions of HNSCC were classified according to the primary site as described in the International Classification of Diseases (ICD-10) for Oncology. The anatomical sites reviewed in this study included: i) $28(37.3 \%)$ mouth and perioral region (C00, C01, C02, C04, C05, C06.0, C06.2); ii) 22 (29.3\%) oropharynx (C09-C10) of the patients; and iii) hypopharynx- larynx $25(23.4 \%)(\mathrm{C} 12, \mathrm{C} 13, \mathrm{C} 32)$. Lesions located in the oral cavity were considered as the anterior group and those located in the oropharynx-hypopharynx-larynx as the posterior group. Patients with diagnosis of carcinoma in situ or multiple head and neck carcinomas were excluded. All patients were asked about the occurrence of cancer in a first degree relative. The term cancer was defined using the WHO definition of 'an uncontrolled growth and spread of cells that may affect almost any tissue of the body'.

Histological gradation. Histological sections of tissues were stained with hematoxylin-eosin and evaluated under conventional light microscopy. All patients had histologically confirmed squamous cell carcinoma of head and neck. Histopathological classification of the tumors as moderate, or poorly differentiated was based on the World Health Organization criteria (WHO, 1997) (53) and invasive front area was also evaluated as described elsewhere (54).

DNA isolation and bisulfite conversion of DNA for methylationspecific PCR (MSP). DNA was isolated from ten 10- $\mu$ m-thick tissue sections from each tissue block of HNSCC specimens, using the DNeasy Tissue Kit (Qiagen, Chatsworth, CA) according to the manufacturer's protocol. The p16CDKN2A gene methylation profile was evaluated through methylationspecific PCR (MSP). DNA samples were bissulfite-treated for $3 \mathrm{~h}$ and MSP-PCR was performed as described (55) and posteriorly modified (56). Primer sequences, PCR product and polymerase chain reaction thermal conditions for defining methylation status are presented in Table I. The p16CDKN2A promoter methylation status for methylated or unmethylated reactions was identified by a fragment of 150 and $151 \mathrm{bp}$ respectively (Fig. 1).

DNMT3B genotyping. DNMT3B (C46359T) polymorphism was assessed by RFLP (Table I). Polymerase chain reaction for DNMT3B was performed in a total volume of $25 \mu \mathrm{l}$ containing $\sim 100 \mathrm{ng}$ genomic DNA as template, $0.5 \mu \mathrm{l}$ of each primer $(20 \mathrm{pmol} / \mu \mathrm{l}), 2.5 \mu \mathrm{l}$ dNTP-mix $(25 \mathrm{mM}$ of each, Amresco, Ohio, CA, USA), $2.5 \mu 1$ 10X PCR buffer, $1.25 \mu 1$ magnesium chloride $(50 \mathrm{mM})$, and $2.5 \mathrm{U}$ of Platinum Taq DNA polymerase (Invitrogen Life Technologies, Carlsbad, CA, USA).

The 230-bp PCR product from the DNMT3B gene was digested with $B \ln 1$ restriction endonuclease (Sigma-Aldrich, St. Louis, MO, USA), that recognizes a restriction site (C/CTAGG) in $\mathrm{T}$ allele; wild-type $\mathrm{C}$ allele lacks the Bln1 restriction site. The wild-type $\mathrm{C}$ allele has only one band (230-bp), while the polymorphic T allele has two bands (172 and 58-bp). Thus, $10 \mu 1$ amplified DNA was digested with $2.5 \mathrm{U}$ of $\mathrm{B} \ln 1$ for $16 \mathrm{~h}$ at $37^{\circ} \mathrm{C}$. PCR and restriction reactions were performed into a termocycler (Eppendorf AG, Hamburg, Germany) (Fig. 1). DNA sequencing was realized to confirm the DNMT3B genotyping by PCR-RFLP.

Electrophoresis. The PCR products for methylation and digested fragments were verified on $6.5 \%$ polyacrylamide gel electrophoresis at $120 \mathrm{~V}$ of constant voltage for $1.5 \mathrm{~h}$ and stained with silver nitrate. Electrophoresis results were estimated regarding a 100-bp ladder. 
Table I. Primer sequences, PCR product and polymerase chain reaction thermal conditions.

Primer sequences

PCR Refs.
product
(bp)

(bp)

\section{DNMT3B C46358T F 5'-TGGCTACCAGGTCTCCTTGGCC-3' R 5'-GGTAGCCGGGAACTCCACGG-3'}

Methylated $p 16$
230

150

\author{
R 5'-GACCCCGAACCGCGACCGTA-3'
}

Unmethylated $p 16$
151

PCR
thermal conditions

\section{R 5'-CAACCCCAAACCACAACCATAA-3'}

\section{$1 \times 95^{\circ} \mathrm{C}-5$}

Own design $^{\mathrm{a}} \quad 35 \times 95^{\circ} \mathrm{C}-1^{\prime} 68.4^{\circ} \mathrm{C}-1^{\prime} 72^{\circ} \mathrm{C}-1^{\prime}$ $1 \times 72^{\circ} \mathrm{C}-10$

$1 \times 95^{\circ} \mathrm{C}-5^{\prime}$

$35 \times 95^{\circ} \mathrm{C}-1^{\prime} 64^{\circ} \mathrm{C}-1^{\prime} 72^{\circ} \mathrm{C}-1^{\prime}$ $1 \times 72^{\circ} \mathrm{C}-10^{\prime}$

$1 \times 95^{\circ} \mathrm{C}-5^{\prime}$

$35 \times 95^{\circ} \mathrm{C}-1^{\prime} 64^{\circ} \mathrm{C}-1^{\prime} 72^{\circ} \mathrm{C}-1^{\prime}$ $1 \times 72^{\circ} \mathrm{C}-10^{\prime}$

aDesigned based on the GenBank reference sequence (accession no. NG_007290), using the software 'Annhyb' (http://annhyb.free.fr) and Blast (www.ncbi.nlm.nih.gov/blast).

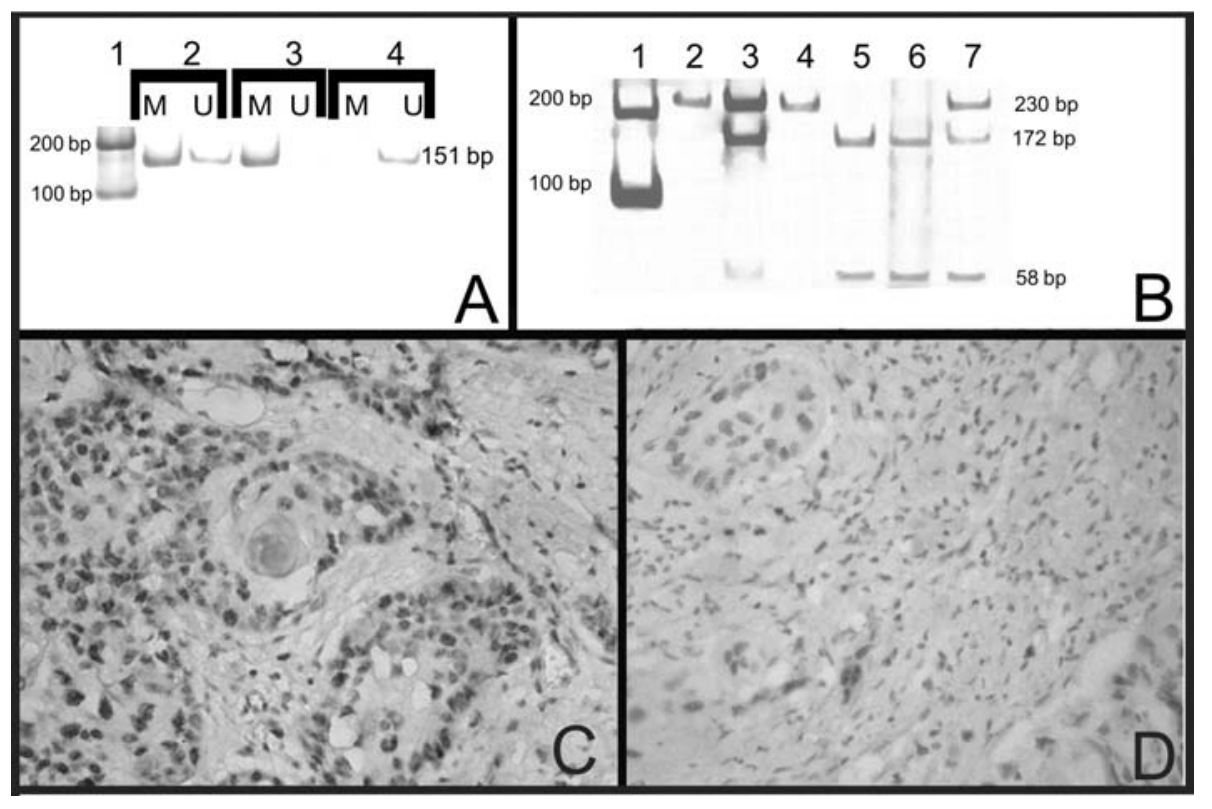

Figure 1. (A) Methylation-specific PCR of p16 gene. 'M' (150 bp) and 'U' (151 bp) represent primer sets specific to methylated and unmethylated DNA, respectively. Samples 2 and 3 contain methylated DNA (M) indicative of the presence $p 16$ methylation. Sample 4 shows the unmethylated status of $p 16$ gene because of absence of methylated reaction (M). Lane 1, 100-bp molecular marker. (B) PCR-RFLP for genotyping of DNMT3B (C46359T) polymorphism. Lane 1, 100-bp molecular marker; lanes 2 and 4, CC genotype; lanes 3 and 7, CT genotype; lanes 5 and 6, TT genotype. (C) Positive immunostaining of DNMT3B, magnification x400. (D) Negative immunostaining of DNMT3B, magnification x400.

Immunohistochemical analyses. Paraffin sections (3- $\mu \mathrm{m})$ were mounted on glass, and dried overnight at $37^{\circ} \mathrm{C}$. All sections were then deparaffinized in xylene, rehydrated through a series of alcohol, and washed in phosphate-buffered saline. AntiDNMT3b monoclonal antibody (diluted 1:250, IMGENEX, CA, USA) was used as the primary antibody and the incubation time was $18 \mathrm{~h}$ at $4^{\circ} \mathrm{C}$. Endogenous peroxidase was blocked by incubation with $0.03 \% \mathrm{H}_{2} \mathrm{O}_{2}$ in ethanol for $30 \mathrm{~min}$. For antigen retrieval, sections were heated in a steam cooker filled for
$5 \mathrm{~min}$ at $125^{\circ} \mathrm{C}$ in Tris-EDTA buffer $(1 \mathrm{mM}$ Tris base, $1 \mathrm{mM}$ EDTA solution, $0.05 \%$ Tween-20, $\mathrm{pH}$ 9.0). Signals were developed with 3'3-diaminobenzidine-tetrahydrocloridre for $5 \mathrm{~min}$ and counter-stained with Harris hematoxylin for $30 \mathrm{sec}$. Normal mucosa was used as positive control and, for negative control, the primary antibody was replaced with phosphate-buffered saline. After staining, tissue sections were scored according to the percentage of positive cells among the neoplastic cells. 
Table II. p16 methylation and their association with molecular and clinicopathological features in case and control HNSCC.

\begin{tabular}{llr}
\hline & \multicolumn{2}{c}{$\begin{array}{c}\text { All patients (\%) } \\
p 16 \text { methylation status }\end{array}$} \\
\cline { 2 - 3 } Variables & Positive & Negati \\
\hline Age & $17(68)$ & $8(32)$ \\
Younger & $42(84)$ & $8(16)$ \\
Older & & 0.099 \\
p-value & &
\end{tabular}

Gender

Male

Female

p-value

Family history of any cancer

$$
\begin{aligned}
& \text { Absent } \\
& \text { Present } \\
& \text { p-value }
\end{aligned}
$$

$$
\begin{array}{cr}
53(89.8) & 11(68.7) \\
06(10.2) & 05(31.3) \\
& \mathbf{0 . 0 3 5}
\end{array}
$$

Younger patients (\%)
p16 methylation status

Positive Negative

$$
\begin{array}{cr}
29(49.2) & 10(62.5) \\
30(50.8) & 06(37.5) \\
& 0.343
\end{array}
$$

Older patients $(\%)$ p16 methylation status

Positive Negative

Smoking status

Smokers

Non-smokers

Ex-smokers

p-value

$$
\begin{array}{lrr}
16(94.1) & 05(62.5) \\
01 & (5.9) \quad 03(37.5)
\end{array}
$$

$$
\begin{array}{cr}
05(29.4) & 06(75.0) \\
12(70.6) & 02(25.0) \\
0 & \mathbf{0 . 0 3 2}
\end{array}
$$

$$
\begin{array}{cr}
37(88.1) & 06(75.0) \\
05(11.9) & 02(25.0) \\
& 0.328
\end{array}
$$

$$
\begin{array}{cr}
24(57.1) & 04(50.0) \\
18(42.9) & 05(50.0) \\
0.709
\end{array}
$$

Alcohol consumption

\section{Drinkers \\ Non-drinkers \\ Ex-drinkers \\ p-value}

Anatomic sites

\section{Anterior \\ Posterior}

p-value

TNM clinical stage

I/II
III/IV
p-value

Tumor size

T1/T2

p-value

Locoregional metastasis

Absent
Present
p-value

WHO grade

$$
\begin{aligned}
& \text { I } \\
& \text { II }
\end{aligned}
$$$$
\text { III }
$$

$$
\begin{array}{crrr}
47(79.7) & & 13(81.3) \\
0(0.0) & & 03(18.7) \\
12(20.3) & & 0 \quad(0.0) \\
\multicolumn{3}{c}{\mathbf{0 . 0 0 1}} &
\end{array}
$$

$$
\begin{aligned}
& 14 \text { (82.4) } \\
& 07 \text { (87.5) } \\
& \begin{array}{ll}
0 & (0.0)
\end{array} \\
& 01 \text { (12.5) } \\
& 03 \text { (17.6) } \\
& 0 \quad(0.0) \\
& 0.169
\end{aligned}
$$

$$
\begin{array}{ll}
12(70.6) & 03(37.5) \\
01 \quad(5.9) & 01(12.5) \\
04(23.5) & 04(50.0) \\
0 & 0.289
\end{array}
$$$$
0.318
$$

$$
\begin{array}{ll}
04(23.5) & 05(62.5) \\
13(81.3) & 03(18.8)
\end{array}
$$$$
0.176
$$$$
0.075
$$

33 (78.6)

06 (75.0)

$0 \quad(0.0) \quad 02(25.0)$

$09(21.4) \quad 0 \quad(0.0)$

\subsection{2}

$$
\begin{array}{lr}
25(59.5) & 04(50.0) \\
02(4.8) & 01(12.5) \\
15(35.7) & 03(37.5) \\
\multicolumn{2}{c}{0.676}
\end{array}
$$

$$
\begin{array}{cr}
15(35.7) & 04(50.0) \\
27(87.1) & 04(12.9) \\
& 0.351
\end{array}
$$

\begin{tabular}{lrrrrrr}
$06(10.2)$ & $03(18.8)$ & $02(11.8)$ & $01(12.5)$ & $04(9.5)$ & $02(25.0)$ \\
$53(89.8)$ & $13(81.2)$ & $15(88.2)$ & $07(87.5)$ & $38(90.5)$ & $06(75.0)$ \\
\multicolumn{2}{c}{0.349} & \multicolumn{2}{c}{0.958} & \multicolumn{2}{c}{0.217}
\end{tabular}

\begin{tabular}{lrrrrr}
$13(22.0)$ & $07(43.8)$ & $04(23.5)$ & $04(50.0)$ & $09(21.4)$ & $03(37.5)$ \\
$46(78.0)$ & $09(56.2)$ & $13(76.5)$ & $04(50.0)$ & $33(78.6)$ & $05(62.5)$ \\
\multicolumn{2}{c}{0.081} & \multicolumn{2}{c}{0.186} & \multicolumn{2}{c}{0.329}
\end{tabular}

\begin{tabular}{lrrrrr}
$21(35.6)$ & $06(37.5)$ & $05(29.4)$ & $03(37.5)$ & $16(38.1)$ & $03(37.5)$ \\
$38(60.4)$ & $10(62.5)$ & $12(70.6)$ & $05(62.5)$ & $26(61.9)$ & $05(62.5)$ \\
\multicolumn{2}{c}{0.888} & \multicolumn{2}{c}{0.686} & \multicolumn{2}{c}{0.975}
\end{tabular}

$\begin{array}{lllllr}17(28.8) & 02(12.5) & 02(11.8) & 02(25.0) & 15(35.7) & 0(0.0) \\ 18(30.5) & 06(37.5) & 09(52.9) & 03(37.5) & 09(21.4) & 03(37.5) \\ 24(40.7) & 08(50.0) & 06(35.3) & 03(37.5) & 18(42.9) & 05(62.5)\end{array}$


Table II. Continued.

\begin{tabular}{|c|c|c|c|c|c|c|}
\hline \multirow[b]{2}{*}{ Variables } & \multicolumn{2}{|c|}{$\begin{array}{c}\text { All patients }(\%) \\
\text { p16 methylation status }\end{array}$} & \multicolumn{2}{|c|}{$\begin{array}{l}\text { Younger patients }(\%) \\
\text { p16 methylation status }\end{array}$} & \multicolumn{2}{|c|}{$\begin{array}{c}\text { Older patients }(\%) \\
\text { p16 methylation status }\end{array}$} \\
\hline & Positive & Negative & Positive & Negative & Positive & Negative \\
\hline \multicolumn{7}{|l|}{ Invasive front grade } \\
\hline Score $4-8$ & $05 \quad(8.5)$ & $0 \quad(0.0)$ & $01(5.9)$ & $0 \quad(0.0)$ & $04 \quad(9.5)$ & $(0.0)$ \\
\hline Score $>8$ & $54(91.5)$ & $16(100.0)$ & $16(94.1)$ & $08(100.0)$ & $38(90.5)$ & $08(100.0)$ \\
\hline $\mathrm{p}$-value & \multicolumn{2}{|c|}{0.288} & \multicolumn{2}{|c|}{0.489} & \multicolumn{2}{|c|}{0.363} \\
\hline \multicolumn{7}{|l|}{ DNMT3B genotype } \\
\hline $\mathrm{CC}$ & $10(16.9)$ & $03(18.8)$ & $03(17.6)$ & $02 \quad(25.0)$ & $07(16.7)$ & $01 \quad(12.5)$ \\
\hline $\mathrm{CT}$ & $41(69.5)$ & $11(68.8)$ & $11(64.8)$ & $06 \quad(75.0)$ & $30(71.4)$ & $05 \quad(62.5)$ \\
\hline $\mathrm{TT}$ & $08(13.6)$ & $02(12.5)$ & $03(17.6)$ & $0 \quad(0.0)$ & $05(11.9)$ & $02 \quad(25.0)$ \\
\hline p-value & \multicolumn{2}{|c|}{0.983} & \multicolumn{2}{|c|}{0.440} & \multicolumn{2}{|c|}{0.615} \\
\hline \multicolumn{7}{|l|}{ Allele frequency } \\
\hline $\mathrm{C}$ allele & $51(86.4)$ & $14(87.5)$ & $14(82.4)$ & $08(100.0)$ & $37(88.1)$ & $06 \quad(75.0)$ \\
\hline $\mathrm{T}$ allele & $08(13.6)$ & $02(12.5)$ & $03(17.6)$ & $0 \quad(0.0)$ & 05 (11.9) & $02 \quad(25.0)$ \\
\hline p-value & \multicolumn{2}{|c|}{0.912} & \multicolumn{2}{|c|}{0.296} & \multicolumn{2}{|c|}{0.310} \\
\hline \multicolumn{7}{|c|}{ DMNT3B immunohistochemistry ${ }^{\mathrm{a}}$} \\
\hline Mean rank of positivity & 37.90 & 28.9 & 12.81 & 10.14 & 25.31 & 20.44 \\
\hline p-value & \multicolumn{2}{|c|}{0.133} & \multicolumn{2}{|c|}{0.384} & \multicolumn{2}{|c|}{0.368} \\
\hline
\end{tabular}

In bold, significant p-value $<0.05$. ${ }^{a}$ Analyzed by Kruskal-Wallis test, the other analyzes were done using the $\chi^{2}$ test.

Statistical analysis. Statistical significance of differences between case and control group distributions for alleles, genotypes, methylation status, immunohistochemical analysis and clinicopathological features was determined using Fisher or $\chi^{2}$ tests. The possible association between genotypes and DNMT3B immunostaining was evaluated by Kruskal-Wallis test.

Time to survival was calculated from date of diagnosis to time of last follow-up visit or to time of death. The records of each patient were reviewed, considering the same parameters, for 0-2500 days. All deaths were caused by locoregional and/or metastatic disease. For the purposes of analysis, patients who died without evidence of recurrence were excluded. Time survival was displayed by means of the Kaplan-Meier method for the variables. The results of Kaplan-Meier were compared by the log-rank test. Variables with $\mathrm{p} \leq 0.25$ additional to age, $\mathrm{p} 16 \mathrm{CDKN} 2 \mathrm{~A}$ methylation status, DNMT3B genotypes and immunostaining were included in the Cox proportional hazards multivariate model. Categorical variables considered as referents were those associated with less risk of death in accordance with the literature. All analyses were assessed using SPSS 17.0 (SPSS Inc., Chicago) and statistical significance was set at $\mathrm{p}<0.05$.

\section{Results}

Association of p16CDKN2A promoter methylation, DNMT3b polymorphism and clinicopathological parameters of HNSSC patients. The frequency distributions of $\mathrm{p} 16 \mathrm{CDKN} 2 \mathrm{~A}$ promoter methylation according to age, molecular features and clinicopathological parameters are summarized in Table II. No association between p16CDKN2A methylation and age was observed. In young patients we identified a significant association between $\mathrm{p} 16 \mathrm{CDKN} 2 \mathrm{~A}$ methylation with the presence of family history of cancer and male gender. On the other hand, in the older patients, p16 methylation was significantly increased regarding the presence of smoking habit. Considering all patients, p16 methylation was increased in male and smoker subjects (Table II). Differences in gender habits were observed according to age. In young patients, no differences of tobacco addiction and gender were observed $(\mathrm{p}=0.072)$. However, considering all patients together or only older patients, the male gender was associated with the presence of tobacco habit when compared with women $(\mathrm{p}=0.001)$ (data not shown). No relation between DNMT3B immunostaining and p16CDKN2A methylation was observed.

Table III presents the distribution of molecular and clinicopathological parameters grouped by age and DNMT3B variants. No association between clinicopathological parameters and the polymorphic variables were observed in young patients. The $\mathrm{T}$ allele of DNMT3B genotype was significantly associated with advanced TNM staging and tumor size in the older patients. Considering all samples, the distribution of allele $\mathrm{T}$ was increased in the T3/T4 tumors. No relation between polymorphic variants of DNMT3B gene and $\mathrm{p} 16 \mathrm{CDKN} 2 \mathrm{~A}$ promoter methylation was observed. 
Table III. DNMT3B genotype and their association with p16 methylation and clinicopathological features in case and control HNSCCs.

\begin{tabular}{|c|c|c|c|c|c|c|c|c|c|}
\hline \multirow[b]{2}{*}{ Variables } & \multicolumn{3}{|c|}{ All patients (\%) } & \multicolumn{3}{|c|}{ Younger patients $(\%)$} & \multicolumn{3}{|c|}{ Older patients $(\%)$} \\
\hline & $\mathrm{CC}$ & $\mathrm{CT}$ & TT & $\mathrm{CC}$ & $\mathrm{CT}$ & $\mathrm{TT}$ & $\mathrm{CC}$ & CT & TT \\
\hline \multicolumn{10}{|l|}{ Age } \\
\hline Young & $05(20.0)$ & $17(68.0)$ & $03(12.0)$ & & & & & & \\
\hline Older & $08(16.0)$ & $35(70.0)$ & $07(14.0)$ & & & & & & \\
\hline $\mathrm{p}$-value & & 0.899 & & & & & & & \\
\hline \multicolumn{10}{|l|}{ Gender } \\
\hline Male & $11(84.6)$ & $45(86.5)$ & $08(80.0)$ & $05(100.0)$ & $13(76.5)$ & $03(100.0)$ & $06(75.0)$ & $32(91.4)$ & $05(71.4)$ \\
\hline Female & $02(15.4)$ & $07(13.5)$ & $02(20.0)$ & $(0.0)$ & $04(23.5)$ & $(0.0)$ & $02(25.0)$ & $03 \quad(8.6)$ & $02(28.6)$ \\
\hline p-value & & 0.864 & & & 0.326 & & & 0.235 & \\
\hline
\end{tabular}

Family history of any cancer

$\begin{array}{lllllllllll}\text { Absent } & 05(38.5) & 28(53.8) & 06(60.0) & 01 & (20.0) & 08(47.1) & 02(66.7) & 04(50.0) & 20(57.1) & 04(57.1) \\ \text { Present } & 08(61.5) & 24(46.2) & 04(40.0) & 04 & (80.0) & 09(52.9) & 01(33.3) & 04(50.0) & 15(42.9) & 03(42.9) \\ \text { p-value } & & 0.527 & & & & 0.395 & & & 0.933 & \end{array}$

Smoking status

Smokers

Non-smokers

Ex-smokers p-value

Alcohol consumption

Drinkers

Non-drinkers

Ex-drinkers

p-value

Anatomic sites

Anterior
Posterior

p-value

TNM clinical stage

I/II

III/IV

p-value

Tumor size

$\mathrm{T} 1 / \mathrm{T} 2$

$\mathrm{T} 3 / \mathrm{T} 4$

p-value

Locoregional

metastasis

Absent

Present

p-value

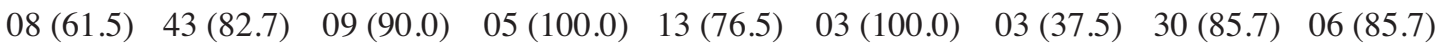

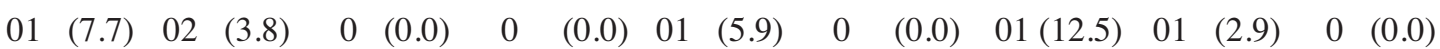
$04(30.8) \quad 07(13.5) \quad 01(10.0) \quad 0 \quad(0.0) \quad 03(17.6) \quad 0 \quad(0.0) \quad 04(15.0) \quad 04(11.4) \quad 01(14.3)$ $\begin{array}{lll}0.437 & 0.692 & 0.054\end{array}$

$05(38.5) \quad 30(57.7) \quad 09(90.0) \quad 02 \quad(40.0) \quad 10(58.8) \quad 03(100.0) \quad 03(37.5) \quad 20(57.1) \quad 06(85.7)$

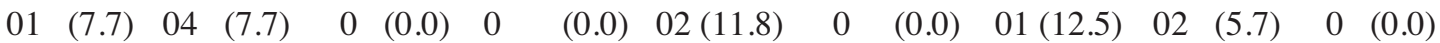

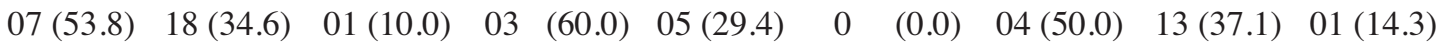
$\begin{array}{lll}0.165 & 0.367 & 0.425\end{array}$

$$
\begin{array}{llllllllllll}
06(21.4) & 20(71.4) & 02 & (7.1) & 02 & (40.0) & 06(35.2) & 01 & (33.3) & 04(50.0) & 14(40.0) & 01(14.3) \\
07(14.9) & 32(68.1) & 08(17.0) & 03 & (18.8) & 11(68.8) & 02 & (12.5) & 04(12.9) & 21(67.7) & 06(19.4) \\
& 0.418 & & & & & 0.976 & & & & 0.330 &
\end{array}
$$

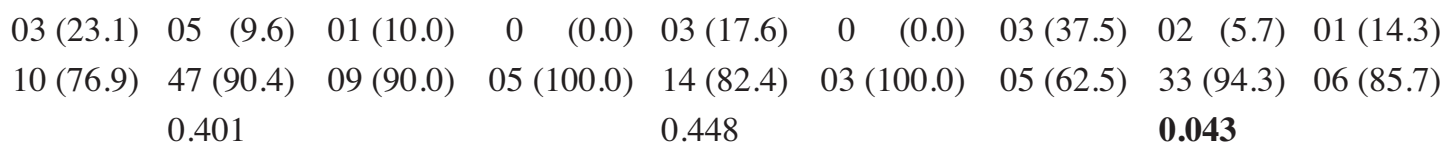

\subsection{1}


Table III. Continued.

\begin{tabular}{|c|c|c|c|c|c|c|c|c|c|c|c|c|}
\hline \multirow[b]{2}{*}{ Variables } & \multicolumn{3}{|c|}{ All patients $(\%)$} & \multicolumn{5}{|c|}{ Younger patients $(\%)$} & \multicolumn{4}{|c|}{ Older patients $(\%)$} \\
\hline & $\mathrm{CC}$ & CT & TT & & $\mathrm{CC}$ & CT & & TT & $\mathrm{CC}$ & $\mathrm{CT}$ & & TT \\
\hline \multicolumn{13}{|c|}{ WHO grade } \\
\hline I & $02(15.4)$ & $14(26.9)$ & $03(30.0)$ & 02 & $(40.0)$ & $02(11.8)$ & 0 & $(0.0)$ & $(0.0)$ & $12(34.3)$ & 03 & $(42.9)$ \\
\hline II & $07(53.8)$ & $14(26.9)$ & $13(30.0)$ & 03 & $(60.0)$ & $07(41.1)$ & 02 & $(66.7)$ & $05(40.0)$ & $07(20.0)$ & 01 & $(14.2)$ \\
\hline III & $04(30.8)$ & $24(46.2)$ & $04(40.0)$ & 0 & $(0.0)$ & $08(47.1)$ & 01 & $(33.3)$ & $05(40.0)$ & $16(45.7)$ & 03 & $(42.9)$ \\
\hline $\mathrm{p}$-value & & 0.461 & & & & 0.250 & & & & 0.214 & & \\
\hline
\end{tabular}

Invasive front

grade

\begin{tabular}{|c|c|c|c|c|c|c|c|c|c|}
\hline Score 4-8 & $01 \quad(7.7)$ & $04 \quad(7.7)$ & $(0.0)$ & $(0.0)$ & $01 \quad(5.9)$ & $(0.0)$ & $01(12.5)$ & 03 (8.6) & $(0.0)$ \\
\hline Score $>8$ & $12(92.3)$ & $48(92.3)$ & $10(100.0)$ & 05 (100.0) & $16(94.1)$ & $03(100.0)$ & $07(87.5)$ & 32 (91.4) & 07 (100.0) \\
\hline p-value & & 0.662 & & & 0.783 & & & 0.656 & \\
\hline
\end{tabular}

p16 methylation

status

Positive

Negative

p-value

$03(23.1) \quad 11(21.2) \quad 02(20.0) \quad 02$

$02 \quad(40.0) \quad 06(35.3) \quad 0$

0.440

05 (71.4)

0.983

$02 \quad(28.6)$

DMNT3B immuno-

histochemistry ${ }^{\mathrm{a}}$

Mean rank of

29.14

$37.54 \quad 35.85$

14.5

11.91

9.7

13.64

26.25

26.86

positivity

$\mathrm{p}$-value

0.472

0.584

0.084

In bold, significant $\mathrm{p}$-value $<0.05 .{ }^{\mathrm{a}}$ Analyzed by Kruskal-Wallis test, the other analyzes were done using the $\chi^{2}$ test.

Moreover, neither polymorphic variables nor clinicopathological parameters showed association with immunoexpression of DNMT3B.

Molecular results and survival of HNSSC patients. The mean overall survival of patients was 1021.5 days after the diagnosis. Factors which impacted in survival were differently distributed among the groups. In young patients no factor was associated with death. Considering both groups together, only TNM staging impacted on survival. However, in older patients, not only TNM staging but also the absence of p16CDKN2A promoter methylation showed a negative impact on survival (Table IV).

\section{Discussion}

The determinants of DNMT expression in human tissues have not been clearly defined. Recently, the role of ageing in DNA methylation was reported in liver cells (57). On the other hand, methylation of tumor suppressor genes, such as p16, has been associated with HNSCC development $(48,58,59)$. In the present study we hypothesized that DNMT3B C46359T polymorphism may be associated with DNMT3B immuno-expression and p16CDKN2A methylation.
In addition, we tested if these parameters are related to the clinical stage, family history or the prognosis of HNSCC in young and older patients matched by the TNM staging, smoking and alcohol intake.

We observed that the frequency of p16 methylation in young patients was not different from older patients with HNSCC and we noted that this epigenetic alteration was present in most of the samples of both groups (76\%). Taken together, the data indicate that p16 methylation is a common event in HNSCC development. Our data showed also that p16 methylation in young patients was associated with family history of cancer. However, there are some limitations that should be regarded. The high presence of subjects with family history of cancer in the young patients group could be a confounding factor. Therefore, a larger scale study is needed to confirm these data. Although we found association between p16 methylation in young patients and male gender, the limited number of patients of female gender indicates that the data must be analyzed cautiously.

We observed that p16CDKN2A methylation in older patients was significantly associated with smoking habit. Smoking is an important factor associated with the methylation of genes related to cancer $(59,60)$. 7-methylguanine (m7Gua) is a biomarker of methylating agents present in tobacco (61). 
Table IV. Cox regression analyses in the HNSCC patients with a follow-up of 0-2500 days.

\begin{tabular}{|c|c|c|c|c|c|c|c|c|c|c|c|c|}
\hline \multirow[b]{2}{*}{ Variables } & \multicolumn{4}{|c|}{$\begin{array}{l}\text { All patients } \\
95.0 \% \mathrm{CI}\end{array}$} & \multicolumn{4}{|c|}{$\begin{array}{l}\text { Young patients } \\
95.0 \% \mathrm{CI}\end{array}$} & \multicolumn{4}{|c|}{$\begin{array}{l}\text { Older patients } \\
95.0 \% \mathrm{CI}\end{array}$} \\
\hline & p-value & OR & Lower & Upper & $\mathrm{p}$-value & OR & Lower & Upper & p-value & OR & Lower & Upper \\
\hline \multicolumn{13}{|l|}{ Age } \\
\hline$>45$ years & Referent & & & & - & - & - & - & - & - & - & - \\
\hline$\leq 45$ years & 0.115 & 1.822 & 0.864 & 3.844 & - & - & - & - & - & - & - & - \\
\hline \multicolumn{13}{|l|}{ P16 methylation } \\
\hline Positive & Referent & & & & Referent & & & & Referent & & & \\
\hline Negative & 0.274 & 1.482 & 0.733 & 2.996 & 0.088 & 0.268 & 0.059 & 1.217 & 0.001 & 7.832 & 2.796 & 21.940 \\
\hline \multicolumn{13}{|l|}{$\begin{array}{l}\text { DNMT3B } \\
\text { genotype }\end{array}$} \\
\hline $\mathrm{CC}$ & Referent & & & & Referent & & & & Referent & & & \\
\hline $\mathrm{CT}$ & 0.822 & 1.110 & 0.449 & 2.744 & 0.438 & 1.991 & 0.350 & 11.336 & 0.973 & 0.980 & 0.297 & 3.233 \\
\hline TT & 0.871 & 1.096 & 0.362 & 3.318 & 0.327 & 0.286 & 0.023 & 3.496 & 0.824 & 1.168 & 0.297 & 4.595 \\
\hline \multicolumn{13}{|l|}{ TMN } \\
\hline Early & Referent & & & & Referent & & & & Referent & & & \\
\hline Late & 0.029 & 5.022 & 1.175 & 21.470 & 0.985 & NA & 0.011 & 8.449 & 0.011 & 8.449 & 1.622 & 44.015 \\
\hline $\begin{array}{l}\text { DNMT3B immuno- } \\
\text { histochemistry }\end{array}$ & 0.753 & 1.141 & 0.501 & 2.597 & 0.583 & 0.666 & 0.156 & 2.848 & 0.079 & 2.623 & 0.894 & 7.696 \\
\hline
\end{tabular}

In bold, significant $\mathrm{p}$-value $<0.05$. The term referent is associated with categorical variables with a lower risk of developing the disease. NA, not applicable.

Recent reviews observed that age and cigarette smoking were positively correlated with the urinary m7Gua level (62). The urinary excretion of m7Gua was shown to be higher in smokers than in non-smokers (63). Furthermore, the m7Gua level in human urine decreased after smoking cessation (64). It is important to highlight that, in the present study, no p16CDKN2A methylation was observed in non-smokers. Therefore, our study gives additional support that both smoking and aging are important factors involved in DNA methylation.

In recent years, several studies have demonstrated that genetic polymorphisms are associated with susceptibility to, or protection from, cancer development $(36,65,66)$. Until now, 13 polymorphisms were described in the coding region of gene DNMT3B according NCBI database, but the association between these genetic variations and cancer prognosis remains unclear. Polymorphisms may alter gene transcription and/or protein synthesis and function. Recently, an increased risk of HNSCC development was demonstrated with the T allele of DNMT3B -149 polymorphism in oral cavity, pharynx and larynx but not in nasopharynx (36). In the present study we attempted to verify the possible association between this polymorphism and early HNSCC development. We did not observe association between DNMT3B polymorphic variant and age, but in the older patients group we found association between the higher DNMT3B genotype (allele T) with an advanced TNM staging. Although this finding suggests that polymorphisms might influence cancer progression, it will take a long time to prove this association. Here, the immunoexpression of DNMT3B protein was not related to the genetic polymorphisms in HNSCC samples studied. Moreover, this polymorphism did not show association with p16 methylation. This may be explained by the fact that other factors, such as HPV high-risk infection, may induce p16 methylation $(47,67)$. Furthermore, other DNMT polymorphisms may be more relevant to this epigenetic alteration.

Evidence suggests that there are differences in molecular mechanisms between younger and older HNSCC patients $(6,9)$. We found that absence of p16 methylation was associated with low survival in older patients. Therefore, it can be speculated that different epigenetic and genetic pathways may affect cancer evolution and prognosis. Although we are only just starting to understand the impact of molecular findings in patient prognosis, previous reports have already suggested that HPV infection has an impact on the prognosis of $\operatorname{HNSCC}(68,69)$.

In conclusion, our data suggest that while genetic factors are more importantly involved with p16 methylation in younger individuals with HNSCC, environmental factors are more relevant for this epigenetic change in older patients. Finally, the present study shows that p16 methylation status has impact on the prognosis of patients with HNSCC. 


\section{Acknowledgements}

This study was supported by grants from Conselho Nacional de Desenvolvimento Científico e Tecnológico (CNPq) and Fundação de Amparo a Pesquisa do Estado de Minas Gerais (FAPEMIG). Dr Guimarães, Dr Moreira and Dr Gomez are research fellows of CNPq. Dr De Paula is a research fellow of FAPEMIG.

\section{References}

1. Parkin DM: Global cancer statistics in the year 2000. Lancet Oncol 2: 533-543, 2001.

2. Parkin DM, Bray F, Ferlay J and Pisani P: Global cancer statistics, 2002. CA Cancer J Clin 55: 74-108, 2005.

3. Argiris A, Karamouzis MV, Raben D and Ferris RL: Head and neck cancer. Lancet 371: 1695-1709, 2008.

4. National Cancer Institute (INCA): Estimate 2008: Brazilian cancer incidence. http://www inca gov br/regpop. Instituto Nacional de Câncer.Coordenação de Prevenção e Vigilância, 2007.

5. Argiris A and Eng C: Epidemiology, staging and screening of head and neck cancer. Cancer Res Treat 114: 15-60, 2003.

6. De Paula AM, Souza LR, Farias LC, et al: Analysis of 724 cases of primary head and neck squamous cell carcinoma (HNSCC) with a focus on young patients and p53 immunolocalization. Oral Oncol 45: 777-782, 2009.

7. Garavello W, Spreafico R and Gaini RM: Oral tongue cancer in young patients: a matched analysis. Oral Oncol 43: 894-897, 2007.

8. Gawecki W, Kostrzewska-Poczekaj M, Gajecka M, Milecki P, Szyfter K and Szyfter W: The role of genetic factor in etiopathogenesis of squamous cell carcinoma of the head and neck in young adults. Eur Arch Otorhinolaryngol 264: 1459-1465, 2007.

9. Llewellyn CD, Johnson NW and Warnakulasuriya S: Factors associated with delay in presentation among younger patients with oral cancer. Oral Surg Oral Med Oral Pathol Oral Radiol Endod 97: 707-713, 2004.

10. Manuel S, Raghavan SK, Pandey M and Sebastian P: Survival in patients under 45 years with squamous cell carcinoma of the oral tongue. Int J Oral Maxillofac Surg 32: 167-173, 2003.

11. Myers JN, Elkins T, Roberts D and Byers RM: Squamous cell carcinoma of the tongue in young adults: increasing incidence and factors that predict treatment outcomes. Otolaryngol Head Neck Surg 122: 44-51, 2000.

12. Siriwardena BS, Tilakaratne A, Amaratunga EA, et al: Analysis of histopathological and immunohistochemical differences of oral squamous cell carcinoma in young and old patients in Sri Lanka. J Oral Pathol Med 36: 357-362, 2007.

13. Chitapanarux I, Lorvidhaya V, Sittitrai P, et al: Oral cavity cancers at a young age: analysis of patient, tumor and treatment characteristics in Chiang Mai University Hospital. Oral Oncol 42: 83-88, 2006.

14. Kannan K, Latha PN and Shanmugam G: Expression of bcl-2 oncoprotein in Indian oral squamous cell carcinomas. Oral Oncol 34: 373-376, 1998

15. Scully C, Field JK and Tanzawa H: Genetic aberrations in oral or head and neck squamous cell carcinoma (SCCHN): 1 . Carcinogen metabolism, DNA repair and cell cycle control. Oral Oncol 36: 256-263, 2000.

16. Toruner GA, Ulger C, Alkan M, et al: Association between gene expression profile and tumor invasion in oral squamous cell carcinoma. Cancer Genet Cytogenet 154: 27-35, 2004.

17. Herman JG and Baylin SB: Gene silencing in cancer in association with promoter hypermethylation. N Engl J Med 349: 2042-2054, 2003.

18. Jones PA and Baylin SB: The fundamental role of epigenetic events in cancer. Nat Rev Genet 3: 415-428, 2002.

19. Feinberg AP: The epigenetics of cancer etiology. Semin Cancer Biol 14: 427-432, 2004.

20. Momparler RL: Cancer epigenetics. Oncogene 22: 6479-6483, 2003.

21. Ducasse M and Brown MA: Epigenetic aberrations and cancer. Mol Cancer 5: 60, 2006.

22. Teodoridis JM, Strathdee G and Brown R: Epigenetic silencing mediated by $\mathrm{CpG}$ island methylation: potential as a therapeutic target and as a biomarker. Drug Resist Updat 7: 267-278, 2004.

23. Gronbaek K, Hother C and Jones PA: Epigenetic changes in cancer. APMIS 115: 1039-1059, 2007.
24. Hermann A, Gowher H and Jeltsch A: Biochemistry and biology of mammalian DNA methyltransferases. Cell Mol Life Sci 61: 2571-2587, 2004.

25. Esteller M: $\mathrm{CpG}$ island hypermethylation and tumor suppressor genes: a booming present, a brighter future. Oncogene 21 : 5427-5440, 2002

26. Shaw RJ, Hall GL, Woolgar JA, Lowe D, Rogers SN, Field JK, Liloglou T and Risk JM: Quantitative methylation analysis of resection margins and lymph nodes in oral squamous cell carcinoma. Br J Oral Maxillofac Surg 45: 617-622, 2007.

27. Calmon MF, Colombo J, Carvalho F, et al: Methylation profile of genes CDKN2A (p14 and p16), DAPK1, CDH1 and ADAM23 in head and neck cancer. Cancer Genet Cytogenet 173: 31-37, 2007.

28. Auerkari EI: Methylation of tumor suppressor genes p16(INK4a), p27(Kip1) and E-cadherin in carcinogenesis. Oral Oncol 42: 5-13, 2006

29. Jones JS, Amos CI, Pande M, et al: DNMT3b polymorphism and hereditary nonpolyposis colorectal cancer age of onset. Cancer Epidemiol Biomarkers Prev 15: 886-891, 2006.

30. Mizuno S, Chijiwa T, Okamura T, et al: Expression of DNA methyltransferases DNMT1, 3A and 3B in normal hematopoiesis and in acute and chronic myelogenous leukemia. Blood 97: $1172-1179,2001$

31. Montgomery KG, Liu MC, Eccles DM and Campbell IG: The DNMT3B $\mathrm{C} \rightarrow \mathrm{T}$ promoter polymorphism and risk of breast cancer in a British population: a case-control study. Breast Cancer Res 6: R390-R394, 2004.

32. Nagai M, Nakamura A, Makino R and Mitamura K: Expression of DNA (5-cytosin)-methyltransferases (DNMTs) in hepatocellular carcinomas. Hepatol Res 26: 186-191, 2003.

33. Patra SK, Patra A, Zhao H and Dahiya R: DNA methyltransferase and demethylase in human prostate cancer. Mol Carcinog 33: 163-171, 2002.

34. Robertson KD, Uzvolgyi E, Liang G, et al: The human DNA methyltransferases (DNMTs) 1, 3a and 3b: coordinate mRNA expression in normal tissues and overexpression in tumors. Nucleic Acids Res 27: 2291-2298, 1999.

35. Chang KP, Hao SP, Liu CT, et al: Promoter polymorphisms of DNMT3B and the risk of head and neck squamous cell carcinoma in Taiwan: a case-control study. Oral Oncol 43: 345-351, 2007.

36. Liu Z, Wang L, Wang LE, Sturgis EM and Wei Q: Polymorphisms of the DNMT3B gene and risk of squamous cell carcinoma of the head and neck: a case-control study. Cancer Lett 268: 158-165, 2008

37. Wang L, Rodriguez M, Kim ES, et al: A novel C/T polymorphism in the core promoter of human de novo cytosine DNA methyltransferase 3B6 is associated with prognosis in head and neck cancer. Int J Oncol 25: 993-999, 2004.

38. Shen H, Wang L, Spitz MR, Hong WK, Mao L and Wei Q: A novel polymorphism in human cytosine DNA-methyltransferase$3 \mathrm{~B}$ promoter is associated with an increased risk of lung cancer. Cancer Res 62: 4992-4995, 2002.

39. Singal R, Das PM, Manoharan M, Reis IM and Schlesselman JJ: Polymorphisms in the DNA methyltransferase $3 \mathrm{~b}$ gene and prostate cancer risk. Oncol Rep 14: 569-573, 2005.

40. Wu Y and Lin JS: DNA methyltransferase 3B promoter polymorphism and its susceptibility to primary hepatocellular carcinoma in the Chinese Han nationality population: a casecontrol study. World J Gastroenterol 13: 6082-6086, 2007.

41. Hogg RP, Honorio S, Martinez A, et al: Frequent 3p allele loss and epigenetic inactivation of the RASSF1A tumour suppressor gene from region $3 \mathrm{p} 21.3$ in head and neck squamous cell carcinoma. Eur J Cancer 38: 1585-1592, 2002.

42. Nakahara Y, Shintani S, Mihara M, Ueyama Y and Matsumura T: High frequency of homozygous deletion and methylation of p16(INK4A) gene in oral squamous cell carcinomas. Cancer Lett 163: 221-228, 2001.

43. Reed AL, Califano J, Cairns P, et al: High frequency of p16 (CDKN2/MTS-1/INK4A) inactivation in head and neck squamous cell carcinoma. Cancer Res 56: 3630-3633, 1996.

44. Schneider BG, Gulley ML, Eagan P, Bravo JC, Mera R and Geradts J: Loss of p16/CDKN2A tumor suppressor protein in gastric adenocarcinoma is associated with Epstein-Barr virus and anatomic location in the body of the stomach. Hum Pathol 31: 45-50, 2000.

45. Yakushiji T, Uzawa K, Shibahara T, Noma $H$ and Tanzawa $H$ : Over-expression of DNA methyltransferases and CDKN2A gene methylation status in squamous cell carcinoma of the oral cavity. Int J Oncol 22: 1201-1207, 2003. 
46. Esteller M: The coming of age of DNA methylation in medicine in the genomics and postgenomics era. Clin Immunol 103: 213-216, 2002

47. Lin TS, Lee H, Chen RA, et al: An association of DNMT3b protein expression with $\mathrm{P} 16^{\mathrm{INK} 4 \mathrm{a}}$ promoter hypermethylation in non-smoking female lung cancer with human papillomavirus infection. Cancer Lett 226: 77-84, 2005.

48. Simao TA, Simoes GL, Ribeiro FS, et al: Lower expression of $\mathrm{p} 14^{\mathrm{ARF}}$ and $\mathrm{p} 16^{\mathrm{INK} 4 \mathrm{a}}$ correlates with higher DNMT3B expression in human oesophageal squamous cell carcinomas. Hum Exp Toxicol 25: 515-522, 2006.

49. Wang J, Walsh G, Liu DD, Lee JJ and Mao L: Expression of Delta DNMT3B variants and its association with promoter methylation of p16 and RASSF1A in primary non-small cell lung cancer. Cancer Res 66: 8361-8366, 2006.

50. Parra FC, Amado RC, Lambertucci JR, Rocha J, Antunes CM and Pena SD: Color and genomic ancestry in Brazilians. Proc Natl Acad Sci USA 100: 177-182, 2003.

51. Pimenta JR, Zuccherato LW, Debes AA, et al: Color and genomic ancestry in Brazilians: a study with forensic microsatellites. Hum Hered 62: 190-195, 2006.

52. Sobin LH: TNM: evolution and relation to other prognostic factors. Semin Surg Oncol 21: 3-7, 2003

53. Broders AC: Squamous-cell epithelioma of the skin: a study of 256 cases. Ann Surg 73: 141-160, 1921.

54. Bryne M, Nielsen K, Koppang HS and Dabelsteen E: Reproducibility of two malignancy grading systems with reportedly prognostic value for oral cancer patients. J Oral Pathol Med 20: 369-372, 1991.

55. Goldenberg D, Harden S, Masayesva BG, et al: Intraoperative molecular margin analysis in head and neck cancer. Arch Otolaryngol Head Neck Surg 130: 39-44, 2004

56. Moreira PR, Guimaraes MM, Guimaraes AL, et al: Methylation of P16, P21, P27, RB1 and P53 genes in odontogenic keratocysts. J Oral Pathol Med 38: 99-103, 2009.

57. Xiao Y, Word B, Starlard-Davenport A, Haefele A, Lyn-Cook BD and Hammons G: Age and gender affect DNMT3a and DNMT3b expression in human liver. Cell Biol Toxicol 24: 265-272, 2008

58. Hasegawa M, Nelson HH, Peters E, Ringstrom E, Posner M and Kelsey KT: Patterns of gene promoter methylation in squamous cell cancer of the head and neck. Oncogene 21: 4231-4236, 2002 .
59. Kato K, Hara A, Kuno T, et al: Aberrant promoter hypermethylation of p16 and MGMT genes in oral squamous cell carcinomas and the surrounding normal mucosa. J Cancer Res Clin Oncol 132: 735-743, 2006.

60. Kim DS, Cha SI, Lee JH, et al: Aberrant DNA methylation profiles of non-small cell lung cancers in a Korean population. Lung Cancer 58: 1-6, 2007.

61. Hecht SS: DNA adduct formation from tobacco-specific Nnitrosamines. Mutat Res 424: 127-142, 1999.

62. Tamae K, Kawai K, Yamasaki S, et al: Effect of age, smoking and other lifestyle factors on urinary 7-methylguanine and 8hydroxydeoxyguanosine. Cancer Sci 100: 715-721, 2009.

63. Stillwell WG, Glogowski J, Xu HX, et al: Urinary excretion of nitrate, $\mathrm{N}$-nitrosoproline, 3-methyladenine and 7-methylguanine in a Colombian population at high risk for stomach cancer. Cancer Res 51: 190-194, 1991.

64. Ichiba M, Matsumoto A, Kondoh T, Horita M and Tomokuni K Decreasing urinary PAH metabolites and 7-methylguanine after smoking cessation. Int Arch Occup Environ Health 79: 545-549, 2006.

65. Drummond SN, De ML, Noronha JC and Gomez RS: GSTM1 polymorphism and oral squamous cell carcinoma. Oral Oncol 40: $52-55,2004$

66. Gomes CC, Drummond SN, Guimaraes AL, Andrade CI, Mesquita RA and Gomez RS: P21/WAF1 and cyclin D1 variants and oral squamous cell carcinoma. J Oral Pathol Med 37: 151-156, 2008.

67. Wu MF, Cheng YW, Lai JC, et al: Frequent p16 $16^{\mathrm{INK} 4 \mathrm{a}}$ promoter hypermethylation in human papillomavirus-infected female lung cancer in Taiwan. Int J Cancer 113: 440-445, 2005.

68. Kong CS, Narasimhan B, Cao H, et al: The relationship between human papillomavirus status and other molecular prognostic markers in head and neck squamous cell carcinomas. Int J Radiat Oncol Biol Phys 74: 553-561, 2009.

69. Sedaghat AR, Zhang Z, Begum S, et al: Prognostic significance of human papillomavirus in oropharyngeal squamous cell carcinomas. Laryngoscope 119: 1542-1549, 2009. 